\title{
ANALYSIS OF AVAILABLE CLOTHING USED IN DAILY USE OF COLLEGE GOING GIRLS
}

\author{
Iti Dubey * \\ Ph.D. Research Scholar \\ Department of Textile and Apparel Designing \\ College Of Community and Applied Sciences \\ M.P.U.A.T. Udaipur, \\ Rajasthan
}

\author{
Sudha Babel \\ Professor \\ Department of Textile and Apparel Designing \\ College Of Community and Applied Sciences \\ M.P.U.A.T. Udaipur, \\ Rajasthan
}

Article DOI: https://doi.org/10.36713/epra4912

\begin{abstract}
The present research was undertaken to find out the analysis of available clothing in wardrobe of daily wear clothing of college going girls. It examines clothing preferences, apparel buying habits, and shopping behaviors. A self developed questionnaire was used to collect data. The purpose of this study is to identify major factors that influence clothing preference and selection. 30 sample size (College going girls) was selected from Home Science girls hostel, MPUAT, Udaipur. Results were systematically illustrated with the help of tables. Results confirmed that the respondents cared about their appearance. They indicated that they love to purchase quality fashionable clothing but were neutral about spending a large percentage of their monthly budget on clothing.
\end{abstract}

\section{INTRODUCTION}

The ultimate guide to what every college girl should have in her wardrobe. Includes wardrobe basics for every college student's closet. Women have the luxury of a lot of options when it comes to their wardrobe, which men usually don't, and thank god for that! But having more options usually means that your wardrobe is going to be flooded with clothes. And most of us ladies do end up hoarding clothes like nobody's business. But sadly, we end up pushing those never touched outfits into the dark abyss of all things rejected.

\section{OBJECTIVE}

To analysis of available clothing in wardrobe of college going girls.

\section{METHODOLOGY}

A self structured interview schedule was formulated to collect information from college going girls related to apparels. 30 sample size (College going girls) was selected from Home Science girls hostel, MPUAT, Udaipur. Results of the survey have been systematically illustrated with the help of tables.

\section{RESULTS AND DISCUSSION}

This section of the study shows very clearly the finding and interpretation in the context of objective of the study, thus providing a bird's eye view of the complete study which make this section the most significant crucial part of this study. The results of the study have been systematically illustrated with the help of tables tracing the objective of the present study. 
Table-1 Frequency and Percentage Distribution of Respondents by age

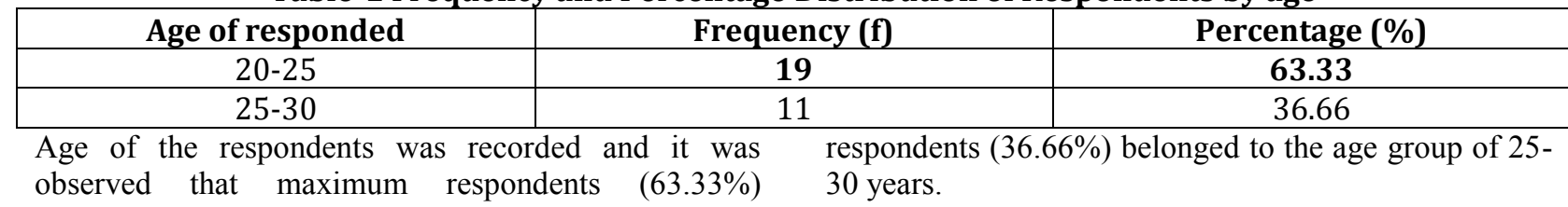

belonged to the age group of 20-24 years and minimum

Table-2 Frequency and Percentage Distribution of Respondents by education

\begin{tabular}{|c|c|c|}
\hline Education of responded & Frequency (f) & Percentage (\%) \\
\hline UG & 2 & 6.66 \\
\hline PG & 13 & 43.33 \\
\hline Ph.D. & $\mathbf{1 5}$ & $\mathbf{5 0}$ \\
\hline
\end{tabular}

The data pertaining to education revealed that all thenad qualification post graduate and only 6.66 per cent respondents were educated. Maximum number ofespondents were undergraduate respondents $(50 \%)$ was $\mathrm{PhD} ., 43.33$ per cent respondents

Table-3 Frequency and Percentage Distribution of Respondents by marital status

\begin{tabular}{|c|c|c|}
\hline Marital status of responded & Frequency (f) & Percentage (\%) \\
\hline Married & 6 & 20 \\
\hline unmarried & $\mathbf{2 4}$ & $\mathbf{8 0}$ \\
\hline
\end{tabular}

The data also revealed that 80 per cent respondents were unmarried and only 20 per cent were married.

Table-4 Frequency and Percentage Distribution of Respondents by family type

\begin{tabular}{|c|c|c|}
\hline Family type of responded & Frequency (f) & Percentage (\%) \\
\hline Nuclear & 8 & 26.66 \\
\hline Joint & 22 & 73.33 \\
\hline
\end{tabular}

Majority of the respondent 73.33 per cent belonged to joint family and only 26.66 per cent respondents belonged to nuclear family.

Table-5 Frequency and Percentage Distribution of Respondents by fabric

\begin{tabular}{|c|c|c|c|}
\hline S.No. & Fabric & Frequency & Percentage \\
\hline 1. & Cotton & $\mathbf{1 8}$ & $\mathbf{6 0}$ \\
\hline 2. & Silk & 6 & 20 \\
\hline 3. & wool & 7 & 23.33 \\
\hline 4. & Synthetic & 20 & 50 \\
\hline 5. & Blended & 5 & 16.67 \\
\hline
\end{tabular}

\section{*Multiple responses}

It is clear from Table 5 that 60 per cent respondents had cotton apparel. 50 per cent used synthetic apparel, 23.33 per cent respondents had wool apparel and only
20 per cent respondents preferred silk and only 16.67 percent blended apparels in their wardrobe.

Table-6 Frequency and Percentage Distribution of Respondents by Preference Criteria

\begin{tabular}{|c|c|c|c|}
\hline S.No. & Preference Criteria & Frequency & Percentage \\
\hline 1. & Appearance & $\mathbf{3 0}$ & $\mathbf{1 0 0}$ \\
\hline 2. & Comfort & $\mathbf{3 0}$ & $\mathbf{1 0 0}$ \\
\hline 3. & Ease of care & 25 & 83.33 \\
\hline
\end{tabular}

\footnotetext{
*Multiple responses
} 
It can be envisaged from the data presented in Table 6 that 100 per cent respondent's preference criteria for selecting the garments are appearance and comfort,
83.33 per cent said they were also giving attention on ease of care .

Table-8 Frequency and Percentage Distribution of Respondents by washing

\begin{tabular}{|c|c|c|c|c|c|}
\hline \multirow{2}{*}{$\begin{array}{c}\text { S. } \\
\text { No. }\end{array}$} & \multirow{2}{*}{ Fabric } & \multicolumn{2}{|c|}{ Dry cleaning } & \multicolumn{2}{c|}{ Hand wash } \\
\cline { 3 - 6 } & & Frequency & Percentage & Frequency & Percentage \\
\hline 1. & Cotton & 2 & 6.66 & $\mathbf{3 0}$ & $\mathbf{1 0 0}$ \\
\hline 2. & Silk & $\mathbf{1 8}$ & $\mathbf{6 0}$ & 5 & 16.66 \\
\hline 3. & wool & 4 & 13.33 & $\mathbf{2 8}$ & $\mathbf{9 3 . 3 3}$ \\
\hline 4. & Synthetic & 3 & 10 & $\mathbf{1 7}$ & $\mathbf{5 6 . 6 6}$ \\
\hline 5. & Blended & 2 & 6.66 & $\mathbf{2 1}$ & $\mathbf{7 0}$ \\
\hline
\end{tabular}

\section{*Multiple responses}

It is clear from table 8 that 100 per cent respondents used hand washing method for cotton garments, and only 6.66 per cent preferred dry cleaning. In case of silk garments 60 per cent respondents used dry cleaning, 16.66 per cent washed through hand .
It was explained by the 93.33 per cent respondents that the washed woolen garments through hand wash method, 13.33 per cent used dry cleaning Synthetic garments washed through hands by 70 per cent respondents, and only 6.66 per cent was using dry cleaning method.

Table-9 Frequency and Percentage Distribution of Respondents by storage method

\begin{tabular}{|l|l|l|l|l|l|}
\hline \multirow{2}{*}{ S. No. } & \multirow{2}{*}{ Fabric } & \multicolumn{4}{c|}{ Storage methods } \\
\cline { 3 - 6 } & & \multicolumn{2}{|c|}{ Homemade method } & \multicolumn{2}{c|}{ Commercial method } \\
\cline { 3 - 6 } & & Frequency & Percentage & Frequency & Percentage \\
\hline 1. & Cotton & $\mathbf{2 4}$ & $\mathbf{8 0}$ & 4 & 13.33 \\
\hline 2. & Silk & $\mathbf{1 5}$ & $\mathbf{5 0}$ & 8 & 26.66 \\
\hline 3. & wool & $\mathbf{2 1}$ & $\mathbf{7 0}$ & 11 & 36.66 \\
\hline 4. & Synthetic & $\mathbf{1 5}$ & $\mathbf{5 0}$ & 3 & 10 \\
\hline 5. & Blended & $\mathbf{2 4}$ & $\mathbf{8 0}$ & 3 & 10 \\
\hline
\end{tabular}

\section{*Multiple responses}

The result revealed that 80 per cent respondents used homemade method for storage of cotton apparels and 13.33 per cent preferred commercial method. 50 per cent respondents used homemade storage method for silk apparels only 26.66 per cent used commercial method. 70 per cent respondents replied they were using homemade method for wool apparels and 36.66 per cent used commercial method. In case of synthetic apparels 50 per cent respondents responded they were also using homemade method and 10 per cent favored commercial method. It was noted that 80 percent respondents were using homemade and 10 per cent commercial method. Most of the respondents said that in homemade method they were using newspaper, neem leaves and in commercial method naphthalene bolls were used.

Table-10 Frequency and Percentage Distribution of Respondents by apparels according to season

\begin{tabular}{|c|c|c|c|}
\hline S.No. & Responses & Frequency & Percentage \\
\hline 1. & Yes & $\mathbf{2 5}$ & $\mathbf{8 3 . 3 3}$ \\
\hline 2. & No & 10 & 16.67 \\
\hline
\end{tabular}

It can be seen from table 10 that 83.33 per cent method depending on type of fabric. 16.67 per cent respondents said that different season require different types of clothing witch further require different storage respondents replied they were not changing the storage method of apparels according to season. 
Table-12 Frequency and Percentage Distribution of Respondents by Money expenditure range monthly

\begin{tabular}{|c|c|c|c|}
\hline S.No. & Money expenditure range monthly & Frequency & Percentage \\
\hline 1. & Below 500 & 08 & 26.66 \\
\hline 2. & $500-1000$ & $\mathbf{1 0}$ & $\mathbf{3 3 . 3 3}$ \\
\hline 3. & $1000-1500$ & 07 & 23.33 \\
\hline 4. & Above 1500 & 07 & 23.33 \\
\hline
\end{tabular}

\section{*Multiple responses}

Most of the respondents (33.33\%) said that they spend 500-1000 Rs/- per month on the purchasing of clothing. 26.22 per cent spend below $500 \mathrm{Rs} /-, 23.33$ per cent spend 1000-1500 Rs/-, and above $1500 \mathrm{Rs} /-$ monthly on clothing.
Arrangement of casual wears and party wears in wardrobe: All the respondents reported that they were keeping their casual wears and party wears separately casual wear folded in separate columns and party wears were hanged in different column.

Table-13 Frequency and Percentage Distribution of Respondents by rearrangement of wardrobe time to time

\begin{tabular}{|l|l|l|l|}
\hline S.No. & Time period & Frequency & Percentage \\
\hline 1. & Twice a week & 2 & 6.66 \\
\hline 2. & Weekly & $\mathbf{1 0}$ & $\mathbf{3 3 . 3 3}$ \\
\hline 3. & After 15 days & 9 & 30 \\
\hline 4. & Monthly & 16 & 53.33 \\
\hline
\end{tabular}

*Multiple responses

It can be seen from Table 13 that 33.33 per cent respondents responded that they were rearrange their wardrobe weekly, 30 per cent rearranged after 15 days,
53.33 per cent rearranged monthly and only 6.66 per cent rearranged twice a week.

Table-14 Frequency and Percentage Distribution of Respondents by Place

\begin{tabular}{|c|c|c|c|}
\hline S.No. & Source of information & Frequency & Percentage \\
\hline 1. & Retailer & 10 & 33.33 \\
\hline 2. & Family and friends & 21 & 70 \\
\hline 3. & Neighbour & 5 & 16.66 \\
\hline 4. & Newspaper & 12 & 40 \\
\hline 5. & Television & 15 & 50 \\
\hline 6. & Radio & 2 & 6.66 \\
\hline 7. & Internet & 22 & 73.33 \\
\hline 8. & Magazine & 20 & 66.66 \\
\hline
\end{tabular}

\section{*Multiple responses}

It can be observed from data that 73.33 per cent respondents said they got information regarding storage methods for garments from the internet.70 percent respondents get information from their family, 66.66 per cent got knowledge from magazine, 50 per cent

Table-17 Frequency and Percentage Distribution of Respondents by place of purchasing

\begin{tabular}{|l|l|l|l|}
\hline S.No. & Place & Frequency & Percentage \\
\hline 1. & Retail shops & 20 & 66.66 \\
\hline 2. & Malls & 22 & 73.33 \\
\hline 3. & Street shops & $\mathbf{2 7}$ & $\mathbf{9 0}$ \\
\hline 4. & online & 9 & 30 \\
\hline
\end{tabular}

\section{*Multiple responses}

The data described that 90 per cent respondents shopping their garments from street shops, 73.33 per cent purchased from malls, 66.66 per cent purchased from television, 40 per cent from newspaper, 33.33 per cent from retailer, 16.66 per cent from neighbour only 6.66 per cent got information from radio.

from, retail shops and only 30 per cent were doing online shopping. 


\section{CONCLUSION}

All respondent were participate during interview process will be done and every one giving very interesting answers as per their need and problem faced .Respondents suggested that used Naphthol balls, dried neem leaves, newspapers these are keep insects, mildew and moth away. Clothes must be kept away from damp places, frequently exposure to sunlight and wind. Don't put dirty/ damp clothes without proper cleaning in wardrobe.

\section{INTER VIEW SCHEDULE}

1) Name:

2) Age:

3) Educational Status:
a. UG
b. $\quad$ PG
c. Ph.D.

4) Marital status:

5) Mobile No.

a. Married

b. unmarried

6) E-mail id:

7) Family type:

a. Nuclear

b. Joint

7) How much apparel do you have in your wardrobe:

\begin{tabular}{|r|c|c|}
\hline S. No. & Fabric & No. of apparel \\
\hline 1. & Cotton & \\
\hline 2. & Silk & \\
\hline 3. & Wool & \\
\hline 4. & Synthetic & \\
\hline 5. & Blended fabric & \\
\hline
\end{tabular}

8) What is yours preference criteria for selecting the garments:
a. Appearance
b. Comfort
c. Ease of care

9) Do you know how to care the different type of garments:
a. Yes
b. No

If yes, how?

10) Which methods do you use for washing the garments:

\begin{tabular}{|c|c|l|l|}
\hline S. No. & Fabric & \multicolumn{2}{|c|}{ Washing methods } \\
\cline { 3 - 4 } & & Hand wash & Dry cleaning \\
\hline 1. & Cotton & & \\
\hline 2. & Silk & & \\
\hline 3. & Wool & & \\
\hline 4. & Synthetic & & \\
\hline 5. & Blended fabric & & \\
\hline
\end{tabular}


11) Which storage method you used for apparels:

\begin{tabular}{|c|c|c|c|}
\hline \multirow{2}{*}{ S. No. } & \multirow{2}{*}{ Fabric } & \multicolumn{2}{|c|}{ Storage methods } \\
\cline { 3 - 4 } & & Homemade method & Commercial method \\
\hline 1. & Cotton & & \\
\hline 2. & Silk & & \\
\hline 3. & Wool & & \\
\hline 4. & Synthetic & & \\
\hline 5. & Blended fabric & & \\
\hline
\end{tabular}

12) Do you change the storage method of apparels according to season:

a. Yes

b. No

14) How much money do you spend on clothing in a monthly:
a. Below 500
b. $500-1000$
c. $1000-1500$
d. Above 1500

15) How you arrange your casual wears and party wears in your wardrobe:

16) Are you rearrange your wardrobe time to time:
a. Yes
b. No

17) In how much time
a. Twice a week
b. Weekly
c. After 15 days
d. Monthly

19) From where you get information regarding storage methods for garments:
a. Retailer
b. Family and friends
c. Neighbour
d. News paper
e. Television
f. Radio
g. Internet
h. Magazine

22) From where you purchase your garments:
a. Online
b. Retail shops
c. Malls
d. Street shops 